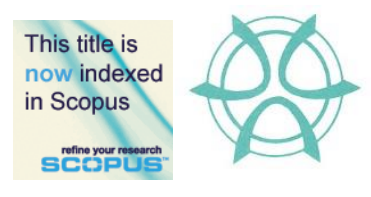

PLANNING MALAYSIA:

Journal of the Malaysian Institute of Planners

VOLUME 16 ISSUE 4 (2018), Page 68 - 80

\title{
RURAL-URBAN MIGRANTS' SENSE OF PLACE IN THE CITY OF BAODING, CHINA
}

\author{
Sun Qingjiu ${ }^{1} \&$ Nor Zarifah Maliki ${ }^{2}$ \\ ${ }^{I}$ College of Architecture and Civil Engineering \\ HEBEI UNIVERSITY CHINA \\ ${ }^{2}$ School of Housing, Building and Planning \\ UNIVERSITI SAINS MALAYSIA
}

\begin{abstract}
From 1978 to 2015 , China's urbanization rate raised from $17.92 \%$ to $56.10 \%$. The rapid urbanization and urban development brought enormous changes in China. Rural-urban migration, the main driver of urban growth in the past few years, has changed the social, spatial, and economic landscapes of Chinese cities but also made the urban scene much more diverse, lively, and dynamic. After migrating to the city, the Chinese migrants are not only subject to difficulties in material aspects of surviving and socializing but also faced with predicaments in re-establishing psychological bonding with the urban environment; due to institutional obstacles such as the household registration system. This paper aims to explore the association between migrants' sense of place and the institutional factor - household registration system. 'Sense of place' is used as a lens to explore and explain migrants' interconnections with the city.
\end{abstract}

Keywords: rural-urban migrants, sense of place, the household registration system 


\section{INTRODUCTION}

After adopting the policy of reform and opening-up at the end of 1978, China has experienced a transformation from a relatively immobile society to one with migrants accounting more than $10 \%$ of China's population (Fan, 2008). As the world's most populous country, the sheer size of migration has affected the economic growth and urban development. From 1980 to 2000, 268 million Chinese, mainly from rural areas migrated to cities (Yusuf \& Saich, 2008). The China One Percent Sample Population Survey in 2005 indicates that the number of migrants reached 147.4 million and rose to 211 million in 2009 (National Population and Family Planning Commission of China [NPFPCC], 2010), and 294 million in 2015 (NBS, 2016).

The bonds of the Chinese migrants to places are seldom studied in the field of people-place relationships. This paper investigates rural-urban migrants' interactions with the urban environment from the perspective of sense of place. Sense of place is a product of a constant process of interaction between people and place. Steele (1981) introduced a sense of place model which consists of two factors: settings (including physical setting and social setting), and the independent and individual "person" (including psychological factors). Lewicka (2011) summarizes these predictors into three rough categories: sociodemographic predictors (referring to people), social predictors (referring to the social setting), and physical predictors (referring to the physical setting).

Hukou, or the Household Registration System in China was introduced in 1958. Hukou has greatly changed the process of rural-urban migration and lives of rural-urban migrants. Therefore, hukou as an institutional factor was incorporated in this study to explore its influence on rural-urban migrants' sense of place.

\section{LITERATURE REVIEW}

\section{Sense of Place}

Place is essential to people's daily life because it is where biological needs including food, water, shelter and proliferation are satisfied (Tuan, 1979). Besides the basic physiological needs, people are also in pursuit for security, belonging, and rootedness from place when they have developed deep experiential connections with place. A sense of place thus is created gradually in the pursuit of physical, social, and psychological demands.

Sense of place is composed of three broad interrelated components: the physical setting (Ismail, Sapian, Scriver, \& Rashid, 2017), the individual's internal psychological and social process, and attributes and activities done at the place (Relph, 1976). Steele (1981) suggests that sense of place is "the pattern of reactions that a setting stimulates for a person. These reactions are a product of both features of the setting and aspects the person brings to it" (p. 12). Gregory, 
Sun Qingjiu \& Nor Zarifah Maliki

Rural-Urban Migrants' Sense of Place in the City of Baoding, China

Johnston, Pratt, Watts and Whatmore (2009) define sense of place as "the attitudes and feelings that individuals and groups hold vis-à-vis the geographical areas in which they live. It further commonly suggests intimate, personal and emotional relationships between self and place" (p. 676). Incorporating attitude theory, Jorgensen and Stedman (2001) propose that sense of place in a multidimensional construct comprises "(1) beliefs about the relationship between self and place; (2) feelings toward the place; and (3) the behavioral exclusivity of the place in relation to alternatives" (p. 233).

\section{Rural-Urban Migrants and the Household Registration System}

In contemporary society, people are very mobile largely due to the development of transportation, information, and communication technologies (Marzukhi, Ling, \& Hamdan, 2017). In China, the emergence of rural-urban migration is the outcome of various factors including not only the economic reason but also the state's decision of relaxing migration control. From being forbidden to being encouraged, the rural-urban migration in China has experienced a complicated process which tightly intertwines with the evolvement of the hukou system.The hukou system has undergone numerous adjustments over the past 50 years. Empirical studies indicate that the hukou still matters for many aspects of urban life, such as job opportunities (Fan, 2002), housing attainment (Wu, 2004), education, and social stratification and mobility (Wu \& Treiman, 2004). The lack of urban hukou causes migrants to suffer many kinds of social exclusion and marginalization in the city (Li, Li, \& Chen, 2010).

\section{METHODOLOGY}

\section{Data}

A survey was conducted between October 2014 to February 2015 on rural-urban migrants who worked and lived in Baoding City, Hebei Province at that time. Two non-probability sampling techniques (snowball sampling and quota sampling) were used because there was no list of all migrants from the official data, nor was the researcher likely to create such a list. The first quota of the survey sample fell into length of residence, as residence length became the most important variables, "even as the sole measure" (Lewicka, 2011, p. 216), in developing sense of place. The second quota addressed home ownership status, as the people-place literature suggested that home ownership was found to be another consistent predictor. The third was urban hukou versus rural hukou. Based on the primary criterion of redundancy, 14 qualitative interviews was also conducted to supplement, validate, and better understand the survey data. 
PLANNING MALAYSIA

Journal of the Malaysia Institute of Planners (2018)

\section{Measurement}

Place differs in scales and attachment may exist at different place scales. This paper only focuses on the rural-urban migrants' sense of place to the city scale. Following the model proposed by Jorgensen and Stedman (2001), rural-urban migrants' sense of place could be inferred from their response of affective, cognitive, and behavioural characteristics. This study considered that the three kinds of response are mediated by the concepts of place attachment, place identity, and place dependence. Place attachment can be regarded as a rural-urban migrant's affective or emotional connection to the urban settings; place identity can be viewed as the perceived rural-urban migrants' cognitions, beliefs, perceptions or thoughts that migrant themselves invested in the urban settings; and place dependence can be defined in terms of the behavioural advantage of a spatial setting compared with other settings. Participants were asked to respond to 11 items concerning their place dependence on city (four items), place attachment to city (three items), and place identity with city (four items).

A single item, "I think that it is important for people living in the city to have a permanent urban residence certificate" was used to explore rural-urban migrants' opinion on the importance of hukou. All items were rated on a 5-point Likert scale, from 1 ("strongly disagree") to 5 ("strongly agree"). The data from the questionnaire survey were analysed with SPSS 18.0.

\section{RESULTS}

\section{Demographic Information of Respondents}

Table 1 presents the socio-demographic characteristics of 431 respondents in the study. The survey was distributed to $50.35 \%$ males $(\mathrm{N}=217)$ and $49.65 \%$ females $(\mathrm{N}=214)$. Most of the respondents were young with $77.49 \%$ of the sample under the age of 39. The majority of the respondents $(\mathrm{N}=351,81.44 \%)$ were married. Most of them reported that they owned their houses $(\mathrm{N}=322,74.71 \%)$, while the rest rented. About two-thirds of the respondents $(\mathrm{N}=287,66.59 \%)$ had gotten an urban hukou.

In-depth interviews were also conducted with 14 interviewees, including nine females and five males, ranging from 21 to 76 years old. Ten participants in the sample owned their houses, while the rest rented houses. Among the 14 respondents, eight of them had the urban hukou, while the rest had not. They had lived in the city for a range of length, from half a year to 28 years, representing a variety of occupations and different education levels. 
Sun Qingjiu \& Nor Zarifah Maliki

Rural-Urban Migrants' Sense of Place in the City of Baoding, China

Table 1: Social-demographic characteristics of the survey sample

\begin{tabular}{|c|c|c|c|c|c|}
\hline & $\mathrm{f}$ & $\%$ & & $\mathrm{f}$ & $\%$ \\
\hline Gender & & & Education & & \\
\hline Male & 217 & 50.35 & Primary school & 4 & 0.93 \\
\hline Female & 214 & 49.65 & $\begin{array}{l}\text { Junior high } \\
\text { school }\end{array}$ & 27 & 6.26 \\
\hline Age & & & $\begin{array}{l}\text { Senior high } \\
\text { school }\end{array}$ & 85 & 19.72 \\
\hline Under 24 & 45 & 10.44 & $\begin{array}{l}\text { Vocational or } \\
\text { technical } \\
\text { training }\end{array}$ & 104 & 24.13 \\
\hline $25-31$ & 114 & 26.45 & $\begin{array}{l}\text { Bachelor } \\
\text { degree }\end{array}$ & 143 & 33.18 \\
\hline $32-38$ & 175 & 40.60 & $\begin{array}{l}\text { Postgraduate } \\
\text { degree }\end{array}$ & 68 & 15.78 \\
\hline $39-45$ & 65 & 15.08 & $\begin{array}{l}\text { Home } \\
\text { ownership } \\
\text { status }\end{array}$ & & \\
\hline 46 and above & 32 & 7.42 & Own & 322 & 74.71 \\
\hline Marital status & & & Rent & 109 & 25.29 \\
\hline Single & 74 & 17.17 & $\begin{array}{l}\text { Residence } \\
\text { length in city } \\
\text { (years) }\end{array}$ & & \\
\hline Married & 351 & 81.44 & Under 3 & 69 & 16.01 \\
\hline Divorced & 4 & 0.93 & $4-6$ & 65 & 15.08 \\
\hline $\begin{array}{l}\text { Widow/Widow } \\
\text { er }\end{array}$ & 2 & 0.46 & $7-10$ & 103 & 23.90 \\
\hline $\begin{array}{l}\text { Having urban } \\
\text { hukou }\end{array}$ & & & $11-20$ & 145 & 33.64 \\
\hline Yes & 287 & 66.59 & Above 20 & 49 & 11.37 \\
\hline No & 144 & 33.41 & & & \\
\hline
\end{tabular}

Source: Authors

\section{Rural-Urban Migrants' Sense of Place in the City}

Respondents were asked to indicate the intensity of their place dependence on the city (CPD), place attachment to the city (CPA), and place identity with the city (CPI). In order to precisely examine their place bonding, an index was created by combining and averaging scores from the three constructs into an overall composite measure - sense of place to the city (CSOP).

Table 2: Mean scores, standard deviations, and the score distribution of the construct of sense of place to the city

\begin{tabular}{|c|c|c|c|c|c|c|c|c|}
\hline & \multicolumn{2}{|c|}{ CPD } & \multicolumn{2}{|c|}{ CPA } & \multicolumn{2}{|c|}{ CPI } & \multicolumn{2}{|c|}{ CSOP } \\
\hline & $\mathrm{f}$ & $\%$ & f & $\%$ & $\mathrm{f}$ & $\%$ & f & $\%$ \\
\hline $1-1.5$ & 8 & 1.86 & 4 & 0.93 & 2 & 0.46 & 0 & 0 \\
\hline $1.5-2$ & 39 & 9.05 & 16 & 3.71 & 7 & 1.62 & 8 & 1.86 \\
\hline $2-2.5$ & 73 & 16.94 & 42 & 9.74 & 30 & 6.96 & 35 & 8.12 \\
\hline $2.5-3$ & 136 & 31.55 & 124 & 28.77 & 116 & 26.91 & 107 & 24.83 \\
\hline $3-3.5$ & 101 & 23.43 & 84 & 19.49 & 132 & 30.63 & 156 & 36.19 \\
\hline
\end{tabular}


PLANNING MALAYSIA

Journal of the Malaysia Institute of Planners (2018)

\begin{tabular}{lcccccccc}
\hline $3.5-4$ & 55 & 12.76 & 129 & 29.93 & 97 & 22.51 & 102 & 23.67 \\
$4-4.5$ & 16 & 3.71 & 20 & 4.64 & 42 & 9.74 & 20 & 4.64 \\
$4.5-5$ & 3 & 0.70 & 12 & 2.78 & 5 & 1.16 & 3 & 0.70 \\
Total & 431 & 100 & 431 & 100 & 431 & 100 & 431 & 100 \\
Mean & 3.00 & & 3.27 & & 3.37 & & 3.21 & \\
$S D$ & 0.66 & & 0.68 & & 0.60 & & 0.53 & \\
Skewness & -0.05 & & -0.16 & & -0.14 & & -0.05 & \\
Kurtosis & 0.10 & & 0.18 & & 0.47 & & 0.05 & \\
\hline
\end{tabular}

Source: Authors

Items were summed and averaged across the number of items in the city scale to measure the intensity of place dependence on, place attachment to, and place identity with the city. Higher scores on the different place constructs were interpreted as higher level of the construct in each case. As illustrated in Table 2, the mean score of place dependence on the city was $3.00(S D=0.66)$ with the most frequent score distribution concentrating on the categories of 2.5-3 $(N=$ $136,31.55 \%$ ). Table 3 shows that the respondents who gave affirmative responses (mean score greater than 3 ) and those who gave negative responses (mean score less than 3 ) were the same (both $40.60 \%$ ) with $18.79 \%$ respondents who answered neutrally (mean score just 3 ). The data manifested that only a small part of the respondents had developed place dependence on the city with the overall level at very low.

Table 3: Summary of response - sense of place to the city

\begin{tabular}{|c|c|c|c|c|c|c|c|c|}
\hline & \multicolumn{2}{|c|}{ CPD } & \multicolumn{2}{|r|}{$\mathrm{CPA}$} & \multicolumn{2}{|c|}{ CPI } & \multicolumn{2}{|c|}{ CSOP } \\
\hline & $f$ & $\%$ & $\mathrm{f}$ & $\%$ & $\mathrm{f}$ & $\%$ & $\mathrm{f}$ & $\%$ \\
\hline $\begin{array}{l}\text { Negative } \\
\text { response }\end{array}$ & 175 & $\begin{array}{c}40.6 \\
0\end{array}$ & $\begin{array}{l}1 \\
0 \\
2\end{array}$ & 23.67 & 69 & 16.01 & $\begin{array}{l}1 \\
3 \\
2\end{array}$ & 30.63 \\
\hline $\begin{array}{l}\text { Neutral } \\
\text { response }\end{array}$ & 81 & $\begin{array}{c}18.7 \\
9\end{array}$ & $\begin{array}{l}8 \\
4\end{array}$ & 19.49 & 86 & 19.95 & $\begin{array}{l}1 \\
8\end{array}$ & 4.18 \\
\hline $\begin{array}{l}\text { Affirmative } \\
\text { response }\end{array}$ & 175 & $\begin{array}{c}40.6 \\
0\end{array}$ & $\begin{array}{l}2 \\
4 \\
5\end{array}$ & 56.84 & 276 & 64.04 & $\begin{array}{l}2 \\
8 \\
1\end{array}$ & 65.20 \\
\hline Total & 431 & 100 & $\begin{array}{l}4 \\
3 \\
1\end{array}$ & 100 & 431 & 100 & $\begin{array}{l}4 \\
3 \\
1 \\
\end{array}$ & 100 \\
\hline
\end{tabular}

Source: Authors

As shown in Table 2, the mean score of place attachment to the city was $3.27(S D=0.68)$ with the most frequent score distribution focusing on the categories of 3.5-4 $(N=129,29.93 \%)$ and 2.5-3 $(N=124,28.77 \%)$. Table 3 illustrated that $56.84 \%$ respondents gave affirmative response, $23.67 \%$ gave negative response while $19.49 \%$ responded neutrally. The results demonstrated that more than half of the respondents had generated place attachment to the city 
Sun Qingjiu \& Nor Zarifah Maliki

Rural-Urban Migrants' Sense of Place in the City of Baoding, China

while the rest had not. Table 2 shows that the mean score of place identity with the city was $3.37(S D=0.60)$ with the most frequent score distributions massing on the categories of 3-3.5 $(N=132,30.63 \%)$ and $2.5-3(N=116,26.91 \%)$. A majority of respondents (64.04\%) gave an affirmative response to place identity, while those who answered negatively and neutrally were $30.63 \%$ and $4.18 \%$, respectively (Table 3 ). The data indicated that most respondents had formed a relatively moderate level of place identity with the city.

Table 4: ANOVA test mean scores of place dependence on, place attachment to, and place identity with the city

\begin{tabular}{|c|c|c|c|c|c|c|c|}
\hline & & $\begin{array}{c}\text { Type } \\
\text { III sum } \\
\text { of } \\
\text { square }\end{array}$ & $d f$ & $\begin{array}{l}\text { Mean } \\
\text { square }\end{array}$ & $F$ & Sig. & $\begin{array}{c}\text { Partial } \\
\text { eta } \\
\text { squared }\end{array}$ \\
\hline NSOP & $\begin{array}{l}\text { Greenhouse- } \\
\text { Geisser }\end{array}$ & 30.87 & 1.97 & 15.68 & 74.48 & 0.000 & 0.15 \\
\hline $\begin{array}{l}\text { Error } \\
\text { (NSOP) }\end{array}$ & & 178.20 & 846.58 & .21 & & & \\
\hline
\end{tabular}

A one-way repeated measures ANOVA was conducted to assess whether the three constructs of sense of place to the city differ significantly. The results in Table 4 showed that the respondents' place dependence on, place attachment to and place identity with the city were significantly different, GreenhouseGeisser adjusted $F(1.97,846.58)=74.48, p<0.05$, partial $\eta^{2}=0.15$.

Table 5: Paired samples tests for place dependence on, place attachment to, and place

\begin{tabular}{|c|c|c|c|c|c|c|c|c|c|}
\hline & & \multirow[b]{2}{*}{ Mean } & \multirow[b]{2}{*}{$S D$} & \multirow{2}{*}{$\begin{array}{c}S D \\
\text { error } \\
\text { mean } \\
\end{array}$} & \multicolumn{2}{|c|}{$95 \% \mathrm{CI}$} & \multirow[b]{2}{*}{$t$} & \multirow[b]{2}{*}{$d f$} & \multirow{2}{*}{$\begin{array}{c}\text { Sig. } \\
(2- \\
\text { tailed) }\end{array}$} \\
\hline & & & & & Lower & Upper & & & \\
\hline $\begin{array}{l}\text { Pair } \\
1\end{array}$ & $\begin{array}{l}\text { CPD- } \\
\text { CPA }\end{array}$ & -0.27 & 0.67 & .03 & -0.33 & -0.21 & -8.39 & 430 & .000 \\
\hline $\begin{array}{l}\text { Pair } \\
2\end{array}$ & $\begin{array}{l}\text { CPD- } \\
\text { CPI }\end{array}$ & -0.36 & 0.66 & .03 & -0.43 & -0.30 & $\begin{array}{c}- \\
11.47\end{array}$ & 430 & .000 \\
\hline $\begin{array}{l}\text { Pair } \\
3\end{array}$ & $\begin{array}{l}\text { CPA- } \\
\text { CPI }\end{array}$ & -0.10 & 0.60 & .03 & -0.15 & -0.04 & -3.29 & 430 & .001 \\
\hline
\end{tabular}

Table 5 illustrated the results of dependent-samples $t$ tests which was conducted to assess whether the constructs of sense of place to the city differed from each other, with each test performed at an alpha level of 0.016 . The score of respondents' place dependence was significantly lower than the score of place attachment, $t(430)=-8.39, p<0.016$, and also significantly lower than the score 
of place identity, $t(430)=-11.47, p<0.016$. The score of place attachment was significantly lower than the score of place identity, $t(430)=-3.29, p<0.016$.

Finally, summing and averaging the mean scores of the three constructs of place dependence, place attachment, and place identity can obtain the respondents' intensity of sense of place to the city. The mean score of sense of place to the city was $3.21(S D=0.53)$ ranging from 1.69 to 4.75 (Table 2). The most frequent score distribution focused on the categories of 3-3.5 $(N=156$, $36.19 \%), 2.5-3(N=107,24.83 \%)$ and 3.5-4 $(N=102,23.67 \%)$. A great majority of respondents $(65.20 \%)$ gave an affirmative response to sense of place to the city, while those who replied negatively and neutrally accounted for $30.63 \%$ and $4.18 \%$, respectively (Table 3). According to the analysis above, it can be concluded that the majority of the respondents had developed sense of place to the city, but its level was not high.

Table 6 shows the results of respondents' opinion on the importance of hukou. The results could be categorized into three groups: 114 respondents $(26.45 \%)$ including those who answered "agree" and "strongly agree" considered the hukou important for their living in the city, 131 respondents (30.39\%) including those who answered "disagree" and "strongly disagree" thought hukou unimportant, and the rest $(\mathrm{N}=186,43.16 \%)$ reported neutral.

Table 6: Descriptive statistics for respondents' opinion on importance of hukou

\begin{tabular}{lcccccc}
\hline & $\begin{array}{c}\text { Strongly } \\
\text { disagree }\end{array}$ & Disagree & Neutral & Agree & $\begin{array}{c}\text { Strongly } \\
\text { agree }\end{array}$ & total \\
\hline Frequency & 46 & 85 & 186 & 91 & 23 & 431 \\
Percent & 10.67 & 19.72 & 43.16 & 21.11 & 5.34 & 100 \\
\hline Source: Authors & & & & &
\end{tabular}

A one-way between subjects ANOVA was conducted to test whether the respondents' sense of place in the city differed significantly between the three groups based on their opinions on the importance of hukou.

Table 7: Means and standard deviations of three groups of importance of hukou for their sense of place

\begin{tabular}{lccc}
\hline & $N$ & Mean & $S D$ \\
\hline Group 1: Disagreeing & 131 & 3.03 & 0.51 \\
Group 2: Neutral & 186 & 3.22 & 0.47 \\
Group 3: Agreeing & 114 & 3.42 & 0.56 \\
Total & 431 & 3.21 & 0.53 \\
\hline
\end{tabular}

Source: Authors 
Sun Qingjiu \& Nor Zarifah Maliki

Rural-Urban Migrants' Sense of Place in the City of Baoding, China

Table 8: Results for the one-way between subjects ANOVA of three groups of importance of hukou for their sense of place

\begin{tabular}{|c|c|c|c|c|c|c|c|}
\hline & $\begin{array}{l}\text { Sum of } \\
\text { squared }\end{array}$ & $d f$ & $\begin{array}{l}\text { Mean } \\
\text { square }\end{array}$ & $F$ & Sig. & $\begin{array}{c}\text { Eta } \\
\text { square }\end{array}$ & $\begin{array}{c}\text { Post } \\
\text { hoc test }\end{array}$ \\
\hline $\begin{array}{l}\text { Between } \\
\text { groups }\end{array}$ & 9.38 & 2 & 4.69 & 17.99 & 0.000 & 0.078 & $\begin{array}{c}\text { Group } 1 \\
< \\
\text { Group } 2 \\
\text { Group } 1\end{array}$ \\
\hline $\begin{array}{l}\text { Within } \\
\text { groups }\end{array}$ & 111.62 & 428 & 0.26 & & & & $\begin{array}{c}< \\
\text { Group } 3 \\
\text { Group } 2\end{array}$ \\
\hline Total & 121.00 & 430 & & & & & $\begin{array}{c}< \\
\text { Group } 3\end{array}$ \\
\hline
\end{tabular}

Table 8 shows that there was significant difference in the scores of sense of place to the city among the three respondents groups, $F(2,428)=17.99, p<$ 0.05 , with eta square 0.078 , which was a medium effect size following Cohen's (1988, pp. 284-287) guidelines. Tukey's post hoc procedure indicated that the mean scores of Group $1(M=3.03, S D=0.51)$ was significantly lower than those in Group $2(M=3.22, S D=0.47)$, and Group $3(M=3.42, S D=0.56)$. The mean scores for Group $2(M=3.22, S D=0.47)$ was significantly lower than those in Group $3(M=3.42, S D=0.56)$ as well. The results showed that respondents' opinion on the importance of hukou significantly correlated with their sense of place in the city.

\section{DISCUSSION}

\section{Rural-Urban Migrants' Sense of Place in the City}

People who migrated to the city usually have explicit aims on themselves or their family members. If the city can well facilitate their goals and activities, the migrants will "perceive themselves as having a strong association with a place" (Stokols \& Shumaker, 1981, p. 457), thus, generating place dependence. Qualitative data showed that many migrants' requirements for higher income and better education for their children could be met through migrating to Baoding. However, the respondents also showed that their other requirements were confined by some invisible limits. Two interviewees lamented on things that they are unable to enjoy with their family due to financial restrictions and the high cost of living in the city. People "develop psychological bonding with [place] largely depends on the extent to which they can exploit that space" (Qian, Zhu, \& Liu, 2011, p. 179).

Qian et al. (2011) also point that in Chinese context, not having local urban hukou limits a migrant's access to resources, social services and facilities, unlike 
PLANNING MALAYSIA

Journal of the Malaysia Institute of Planners (2018)

the officially registered urban residents. In this study, two interviewees stated that they need to pay the school more money as sponsor fee because they didn't have Baoding urban hukou. The limit undoubtedly decreases migrants' place dependence on the city, and that is why migrants report a medium degree of place dependence on city (3.00).

The second dimension of sense of place to city is place attachment which refers to behavioural commitment and emotional bonding of the migrants to the city. Although the respondents showed an affirmative place attachment to city ( $M$ $=3.27$ ), it was worth noting that the level of their place attachment to city was not high either. Individuals evaluate place characteristics according to different subjective standards which have been "the result of differences in past experiences or adaptations to present circumstances" (John, 1987, p. 377). The concrete statement from qualitative data may help to explain this. Respondents' place attachment to the city was developed through their first experiential interactions with the city, especially through some unforgettable experience with people.

According to Robertson (2006), place identity plays a decisive role in keeping people in a place. In this study, migrants' place identity with city is also limited by the degree to which the city meets the migrants' needs. Hence, if needs are met, they prefer to stay in the city; if not, they may leave. The intensity of respondents' place identity with city $(M=3.37)$ reflected their predicaments they stated a positive evaluation of place identity with city, but the level is not high. The degree to what the urban qualities fit their expectations and needs is judged by the benefits and disadvantages provide by the city (Mesch \& Manor, 1998). Qualitative results showed that the city had many advantages that attract migrants such as more job opportunities and better education, but some disadvantages also weakened their place-based identity such as loneliness and isolation of the old migrants, serious air pollution in city, and no retirement security. Another critical finding which was significantly different from previous studies about place identity was that the hukou system greatly affected migrants' situating self-identity within the city.

\section{The Impact of Hukou on Rural-Urban Migrants' Sense of Place}

Previous research on sense of place have not assessed the importance of institutional factor. Therefore, the importance of hukou for migrants living in the city was assessed in this study. Results in this study indicated that hukou had significantly influenced migrants' sense of place to the city. Although the government of China has instituted many reforms to hukou system to make the rural-urban migration easier to live in the city, in fact, the hukou system, as a way to stop the migrants enjoying the basic welfare and public services of urban residents, remains strong. It is hard for the migrants to develop sense of place to the city when their children cannot have an equal education right or when they 
Sun Qingjiu \& Nor Zarifah Maliki

Rural-Urban Migrants' Sense of Place in the City of Baoding, China

cannot enjoy urban medical insurance, just because they don't have urban hukou. One participant said that:

My children do not have Baoding urban residence certificate. We need to pay the school more money as sponsor fee. . . My son studies well at school, but we have to pay a large amount of extra money even if he has admitted to a key high school. . . .

China had built up urban medical insurance scheme for urban residents and new rural cooperative medical system for rural residents. The migrants with rural hukou should attend the new rural cooperative medical system. If they were sick and needed hospital care, the rate of reimbursement for treatment fee was $85 \%-90 \%$ when treated in hospitals in the village and towns; $70 \%-80 \%$ in the county hospital; $60 \%-68 \%$ in the city hospital; and $55 \%$ in the provincial hospital (Health and Family Planning Commission of Hebei Province [HFPCH], 2013). Some of the interviewees complained about this regulation. One female interviewee said that:

The new rural cooperative medical system is a good policy for the farmer, but it is inconvenient for us. ... We live in the city. It is impossible to go to the town hospital or county hospital when we are sick...

A variety of reforms have been instituted to reduce the restriction of hukou system to rural-urban migrants and migration. "The cumulative effect of these reforms is not abolition of the hukou, but devolution of responsibility for hukou policies to local government" (Chan \& Buckingham, 2008, p. 582). If the hukou system sets up "an invisible wall" between rural and urban area initially, another wall, which restricts migration from city to city, is being put up for urbanurban migrants. With this wall, many basic welfares and government-provided services (e.g., a city bus pass or scenic spots' entrance tickets) are only provided to local urban residents, but not to residents who hold urban hukou of other cities. The hukou system not only seriously affect the livelihood of rural-urban migrants, but it also has become "a tool that sharpens social cleavages and entrenches inequality" (Ma, 2015).

\section{CONCLUSION}

The Chinese hukou system provides a unique case to examine how the social institution affected people-place relationships. The integration of institutional factor into a comprehensive exploration of rural-urban migrants' sense of place expands and enriches people-place relationships theory. A city is the best possible place to live in the past, the present, and the foreseeable future (Glaeser, 2011). Rapid urbanization is still ongoing in China, and more and more people are migrating from rural areas to cities. Undoubtedly, the influx of migration is changing the urban social, economic and even political landscapes. The rural- 
urban migrants devote their youth, energy, and efforts in cites - which also contribute to the beauty, prosperity, and improvement of cities - in order to survive, socialize and re-establish psychological bonding within the urban environment. The aim of the city defined by Aristotle is to provide both security and happiness for its inhabitants (Doxiadis, 1976). Migrants' weak intensity of sense of place to the city in this study indicated that they had not obtained dependence, attachment, and identity from cities, and were on the way to pursuing security, happiness and belonging to cities.

\section{REFERENCES}

Chan, K. W., \& Buckingham, W. (2008). Is China abolishing the hukou system? The China Quarterly, 195, 582-606.

Cohen, J. (1988). Statistical power analysis for the behavioral sciences (Second Edition). New York: Psychology Press, Taylor \& Francis Group.

Doxiadis, C. A. (1976). How can we learn about man and his settlements? In A. Papoport (Ed.), The mutual interaction of people and their built environment: a crosscultural perspective (pp. 77-126). Chicago: Mouton Publishers.

Fan, C. C. (2002). The elite, the natives, and the outsiders: Migration and labor market segmentation in urban China. Annals of the Association of American Geographers, 92(1), 103-124.

Fan, C. C. (2008). Migration, hukou, and the city. In S. Yusuf \& T. Saich (Eds.), China urbanizes: Consequences, strategies, and policies (pp. 65-89). Washington, D.C.: The World Bank.

Glaeser, E. (2011). Triumph of the city. New York: The Penguin Press.

Gregory, D., Johnston, R., Pratt, G., Watts, M. J., \& Whatmore, S. (2009). The Dictionary of Human Geography (5th Edition ed.). Chichester, West Sussex, UK: WilleyBlackwell.

Health and Family Planning Commission of Hebei Province [HFPCH] (2013) Hebeisheng 2013 nian xinxing nongcun hezuo yiliao tongchou buchang fang'an jiben kuangjia [The basic framework of the overall compensation scheme for new rural cooperative medical system from 2013 in Hebei province]. Shijiazhuang: Health and Family Planning Commission of Hebei.

Ismail, M. N., Sapian, A. R., Scriver, P., \& Rashid, M. (2017). Translation of social citizenship to architecture and built environment: A methodological review. Planning Malaysia, 15(1), 235-244.

John, C. S. (1987). Racial differences in neighborhood evaluation standards. Urban Affairs Review, 22(3), 377-398.

Jorgensen, B. S., \& Stedman, R. C. (2001). Sense of place as an attitude: Lakeshore owners attitudes toward their properties. Journal of Environmental Psychology, 21(3), 233-248.

Lewicka, M. (2011). Place attachment: How far have we come in the last 40 years? Journal of Environmental Psychology, 31(3), 207-230.

Li, L., Li, S., \& Chen, Y. (2010). Better city, better life, but for whom? The hukou and resident card system and the consequential citizenship stratification in Shanghai. City, Culture and Society, 1(3), 145-154. 
Sun Qingjiu \& Nor Zarifah Maliki

Rural-Urban Migrants' Sense of Place in the City of Baoding, China

Ma, D. (2015, August, 25). China's 20 percent problem. Foreign Affairs.

Marzukhi, M. A., Ling, H. L., \& Hamdan, H. (2017). Urban planning and the challenges of neoliberal globalisation in Malaysia. Planning Malaysia, 15(2), 1-12.

Mesch, G. S., \& Manor, O. (1998). Social ties, environmental perception, and local attachment. Environment and Behavior, 30(4), 504-519.

National Bureau of Statistics of China [NBS] (2016). 2015 Nian guomin jingji he shehui fazhan tongji gongbao [National economy and society developed statistical bulletin 2015]. Beijing: National Bureau of Statistics of China.

National Population and Family Planning Commission of China [NPFPCC] (2010). Zhongguo liudong renkou fazhan baogao 2010 [Report on China's migrant population development 2010]. Beijing: China Population Publishing House.

Qian, J., Zhu, H., \& Liu, Y. (2011). Investigating urban migrants' sense of place through a multi-scalar perspective. Journal of Environmental Psychology, 31(2), 170183.

Relph, E. (1976). Place and placelessness. London: Pion Limited.

Robertson, D. (2006). Hard as the rock itself: Place and identity in the American mining town. Colorado: University Press of Colorado.

Steele, F. (1981). The sense of place. Boston, Massachusetts: CBI Publishing Company.

Stokols, D., \& Shumaker, S. A. (1981). People in places: A transactional view of settings. In J. H. Harvey (Ed.), Cognition, social behavior, and the environment (pp. 441488). Hillsdale, N.J.: Lawrence Erlbaum.

Tuan, Y.-F. (1979). Space and place: Humanistic perspective. In S. Gale \& G. Olsson (Eds.), Philosophy in geography (pp. 387-427). Dordrecht, Holland: D. Reidel Publishing Company.

$\mathrm{Wu}, \mathrm{W}$. (2004). Sources of migrant housing disadvantage in urban China. Environment and Planning, 36(7), 1285-1304.

Wu, X, \& Treiman, D.J. (2004) The household registration system and social stratification in China, 1955 - 1996. Demography, 41(2), 363-384.

Yusuf, S., \& Saich, T. (2008). China urbanizes: Consequences, strategies, and policies. Washington, D.C.: The World Bank.

Received: $1^{\text {st }}$ June 2018. Accepted: $1^{\text {st }}$ December 2018 